\title{
Medical care in a tropical national reference and teaching hospital: outline study of cost-effectiveness
}

\author{
P H REES, L R BAGG, D P HANSEN, J J THUKU
}

British Medical Fournal, 1978, 2, 102-104

\section{Summary and conclusions}

During a 28-day prospective audit the cost-effectiveness of treatment in three types of medical wards in a large tropical teaching hospital was assessed. Patients with chronic diseases such as rheumatic heart disease were more expensive to treat than those with acute, curable illnesses such as malaria.

It was concluded that the cost of providing treatment could not be reduced without affecting standards of medical care. The expense of running such a hospital might also be justified by its important function as a teaching hospital.

\section{Introduction}

Recently the value of large national teaching hospitals in the tropics has been questioned. It has been suggested that much of their medicine contributes little to the health of the community at large, and they have been called "disease palaces for doctors." The World Health Organisation is now directing its energies away from such hospitals towards peripheral services. ${ }^{1}$ Without entering into the argument of priorities, it seemed worth assessing in simple terms the value of care provided by such a hospital. The provision of surgical, paediatric, and obstetric care could probably be similarly assessed, but we confined our analysis to the management of inpatients in three medical wards.

The Kenyatta National Hospital is the university teaching and reference hospital for Kenya, receiving patients from all over the country but particularly from the densely populated area near Nairobi. Before referral patients have been seen and usually investigated and treated to a varying extent at any level from provincial hospitals, headed by specialists, to district hospitals, health centres, or dispensaries, and some are referred by private hospitals or practitioners. Many patients, however, especially those living nearby, are seeking medical care for the first time. Patients present at the Kenyatta Hospital in one of three ways: at the casualty department (acute or serious illness); at the outpatient clinics (generally after referral for chronic conditions);

\footnotetext{
Kenyatta National Teaching Hospital and Department of Medicine, University of Nairobi, PO Box 30588, Nairobi, Kenya

$P$ H REES, MRCP, senior lecturer

L R BAGG, MRCP, lecturer (now clinical research fellow, the London Hospital (Whitechapel), London E1 1BB)

D P HANSEN, MD, lecturer (now at Department of Medicine, University of California, San Diego, California 92010)

J J THUKU, MB, DPH, chief administrator
}

or at the filter clinic, a kind of primary care unit within the hospital, where minor illness and self-referred cases are sorted out.

Every year in these three departments roughly 250000 consultations are given to adult patients with predominantly medical problems, resulting in the admission of about 10000 patients to: (a) the adult observation ward, a 40-bedded unit intended for immediate diagnosis and treatment of patients with acute medical conditions, especially those who are expected to recover fairly rapidly (the ward has its own "side room" for simple laboratory tests); (b) one of the eight general medical wards, which total 204 beds; or (c) the intensive care unit, with up to 10 beds.

\section{Methods}

Prospective audits of all new admissions to the adult observation ward, intensive care unit, and one of the eight medical wards were carried out over 28 days. Clinical data collected were the established diagnosis, the duration of stay in the ward, and the outcome. A simple scheme was devised to classify the value of an admission and treatment (table I), patients being allocated to four groups according to their treatment score. Treatment unimportant to recovery was scored 0 (group 1); treatment resulting in recovery 1 (group 2); treatment useful but not resulting in permanent cure $\frac{1}{2}$ (group 3); and treatment not useful and not leading to recovery 0 (group 4 ). For example, a patient with infectious hepatitis or one with an untreatable malignancy scored 0 , a patient relieved of pulmonary oedema secondary to mitral stenosis scored $\frac{1}{2}$, and a patient cured of a severe infection with Plasmodium falciparum scored 1.

The costs of running each type of ward were averaged on a yearly basis. Building and maintenance costs were ignored as they were similar for all three areas. The intensive care unit and the 25-bed medical ward are roughly the same size, though the adult observation ward is smaller, being designed for 24 beds. It now contains 40 and at times accommodates up to 100 patients. Capital depreciation on equipment was assessed arbitrarily at $20 \%$ a year, though the figure should probably be higher for the sophisticated equipment in the intensive care unit and lower for that in the adult observation and general wards.

In calculating staff costs only basic salaries were considered; we did not think that failure to include additional allowances would introduce any important differences. Costing food, drugs, investigations, and laundry were difficult because of considerable day-to-day

TABLE I-Classification of value of admission to hospital according to influence of treatment on outcome

\begin{tabular}{|c|c|c|c|c|}
\hline \multirow[b]{2}{*}{ Treatment: } & \multicolumn{2}{|c|}{ Complete recovery } & \multicolumn{2}{|c|}{$\begin{array}{l}\text { No recovery or } \\
\text { recovery incomplete }\end{array}$} \\
\hline & $\begin{array}{c}\text { Not } \\
\text { important }\end{array}$ & Important & Useful & $\begin{array}{c}\text { Not } \\
\text { useful }\end{array}$ \\
\hline $\begin{array}{l}\text { Patient group } \\
\text { Value of treatment } \\
\text { (score) }\end{array}$ & $\begin{array}{l}1 \\
0\end{array}$ & $\begin{array}{l}2 \\
1\end{array}$ & $\begin{array}{l}3 \\
\frac{1}{2}\end{array}$ & $\begin{array}{l}4 \\
0\end{array}$ \\
\hline
\end{tabular}


TABLE II-Numbers of patients admitted to three wards in Kenyatta National Hospital, Nairobi, during 28-day audit according to value group, and estimate of effectiveness factors of admissions

\begin{tabular}{|c|c|c|c|c|c|c|c|c|c|c|c|}
\hline \multirow{2}{*}{ Ward } & & & \multirow{2}{*}{$\begin{array}{c}\text { No of } \\
\text { admissions } \\
(y)\end{array}$} & \multirow{2}{*}{$\begin{array}{l}\text { Average } \\
\text { duration } \\
\text { of stay } \\
\text { (days) }\end{array}$} & \multicolumn{4}{|c|}{ Value group* } & \multirow{2}{*}{$\begin{array}{l}\text { No of } \\
\text { deaths }\end{array}$} & \multirow{2}{*}{$\begin{array}{c}\text { Total } \\
\text { value of } \\
\text { admissions* } \\
(\mathbf{x})\end{array}$} & \multirow{2}{*}{$\begin{array}{l}\text { Effectiveness } \\
\text { factor }\left(\frac{x}{y}\right)\end{array}$} \\
\hline & & & & & 1 & 2 & 3 & 4 & & & \\
\hline $\begin{array}{l}\text { General medical ward } \ldots \\
\text { Intensive care unit } \\
\text { Adult observation ward }\end{array}$ & $\begin{array}{l}\because \\
\because\end{array}$ & $\begin{array}{l}\because \\
\because\end{array}$ & $\begin{array}{r}24 \\
40 \\
273\end{array}$ & $\begin{array}{r}28 \\
4 \cdot 5 \\
3 \cdot 2\end{array}$ & $\begin{array}{l}3 \\
1 \\
9\end{array}$ & $\begin{array}{r}4 \\
9 \\
115\end{array}$ & $\begin{array}{c}6 \\
12 \\
138\end{array}$ & $\begin{array}{l}11 \\
18 \\
11\end{array}$ & $\begin{array}{r}8 \\
19 \\
1\end{array}$ & $\begin{array}{r}7 \\
15 \\
184\end{array}$ & $\begin{array}{l}0.292 \\
0.375 \\
0.674\end{array}$ \\
\hline
\end{tabular}

*See table I for details of scoring in each group of patients.

variations, but any errors introduced probably applied equally to all three units. The cost of each admission was calculated by dividing the annual costs of each unit by the total annual admissions, and the costs per effective admission were estimated by dividing the individual admission cost by an "effectiveness factor" derived from the 28-day clinical study.

\section{Results}

The number of admissions to the three units during the 28-day audit periods and their effectiveness factors are shown in table II. Admissions to the intensive care unit and general ward included transfers from other areas of the hospital. Of the 273 patients admitted to the adult observation ward, 56 were not well enough for discharge after the few days' stay normally allowed in the ward, and were transferred either to the general wards, or, if a diagnosis of tuberculosis had been established, to the nearby tuberculosis unit. These patients were included in the costing for the adult observation ward, thus affecting analysis and tending to lower the cost-effectiveness. Usually such patients are not admitted to the adult observation ward, but go direct to the medical wards. A few such patients are inevitably admitted either because the chronic nature of their condition was not recognised or because of a temporary lack of accommodation in the general wards. Patients in group 4 were often too ill to be discharged

TABLE III-Numbers of patients admitted to adult observation and general medical wards and number (all ages) admitted to intensive care unit during 28day audit, according to aetiological classification. Number of deaths given in parentheses

\begin{tabular}{|c|c|c|c|}
\hline Infections & $\begin{array}{c}\text { No of } \\
\text { admissions }\end{array}$ & Others & $\begin{array}{c}\text { No of } \\
\text { admissions }\end{array}$ \\
\hline \multicolumn{4}{|c|}{ Adult observation ward } \\
\hline $\begin{array}{l}\text { Pneumococcal lobar } \\
\text { pneumonia } \ldots \\
\text { Tuberculosis } \ldots \\
\text { Other respiratory tract } \\
\text { infections } \\
\text { Bacillary dysentery and } \\
\text { gastroenteritis.. } \\
\text { Plasmodium falciparum } \\
\text { infection } \\
\text { Amoebic liver abscess and } \\
\text { dysentery } \\
\text { Meningococcal meningiti } \\
\text { Miscellaneous (including } \\
\text { typhoid, leprosy, } \\
\text { syphilis) }\end{array}$ & $\begin{array}{r}29 \\
21 \\
16 \\
20 \\
18 \\
6 \\
4\end{array}$ & 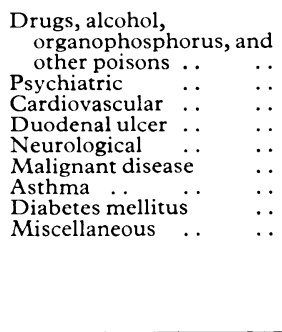 & $\begin{array}{r}25 \\
19 \\
23 \\
16 \\
10 \\
13 \\
8 \\
8 \\
23\end{array}$ \\
\hline Total & 128 & & 145 \\
\hline \multicolumn{4}{|c|}{ General medical ward } \\
\hline $\begin{array}{l}\text { Infectious hepatitis } \\
\text { Hookworm anaemia } \\
\text { Influenza ... } \\
\text { Gastroenteritis }\end{array}$ & $\begin{array}{l}2 \\
2 \\
1 \\
1\end{array}$ & $\begin{array}{l}\text { Malignant disease } \\
\text { Cardiovascular .. } \\
\text { Miscellaneous } \\
\quad \text { bronchiectasis 1, } \\
\text { rheumatoid arthritis 1, } \\
\quad \text { undiagnosed 1, } \\
\quad \text { duodenal ulcer 1) }\end{array}$ & $\begin{array}{l}9 \\
5\end{array}$ \\
\hline Total & 6 & & 18 \\
\hline \multicolumn{4}{|c|}{ Intensive care unit } \\
\hline $\begin{array}{l}\text { Infections (infants) } \\
\text { Cardiac arrest }{ }^{*} \\
\text { Pneumonia (adults) } \\
\text { Poliomyelitis, bulbar }\end{array}$ & $\begin{array}{l}6(2) \\
6(6) \\
2(2) \\
1(0)\end{array}$ & $\begin{array}{ll}\text { Surgical . } & \ldots \\
\text { Acute renai failure } & \ldots \\
\text { Organophosphorus } & \ldots \\
\text { poisoning } & \ldots \\
\text { Rheumatic heart disease }\end{array}$ & $\begin{array}{r}18(6) \\
4(2) \\
2(0) \\
1(1) \\
\end{array}$ \\
\hline Total & $15(10)$ & & $25(9)$ \\
\hline
\end{tabular}

*Five out of six were infants whose initial arrest, which was secondary to infection, occurred before admission to intensive care unit.
TABLE IV-Yearly running costs of three wards in Kenyatta National Hospital, Nairobi

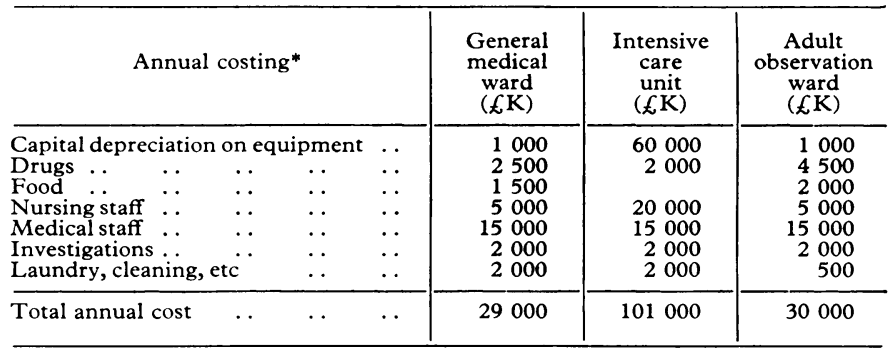

*Building and maintenance and central administrative costs were not estimated, since they were common to all three areas.
$£$ K1 ( 20 Kenyan shillings $)=£ 1.38$, or $\$ 2.44$

TABLE V-Number of yearly admissions to three wards in Kenyatta National Hospital, Nairobi, and cost-effectiveness of admissions

\begin{tabular}{|c|c|c|c|}
\hline & $\begin{array}{l}\text { General } \\
\text { medical } \\
\text { ward }\end{array}$ & $\begin{array}{c}\text { Intensive } \\
\text { care } \\
\text { unit }\end{array}$ & $\begin{array}{l}\text { Adult } \\
\text { observation } \\
\text { ward }\end{array}$ \\
\hline $\begin{array}{l}\text { No of yearly admissions } \\
\text { Average cost per admission ( } \mathbf{x}) \\
\text { Effectiveness factor }(y \text {; see table II) } \\
\text { Cost of each effective admission }(\underline{x})\end{array}$ & $\begin{array}{c}363 \\
£ \mathrm{~K} 80 \\
0.292 \\
£ \mathrm{~K} 274\end{array}$ & $\begin{array}{l}227 \\
£ \mathrm{~K} 445 \\
0 \cdot 375 \\
£ \mathrm{~K} 1187\end{array}$ & $\begin{array}{l}4872 \\
£ K 6 \\
0 \cdot 674 \\
£ K 9\end{array}$ \\
\hline
\end{tabular}

from hospital, and remained in the general wards until they died, constituting an important factor in the longer average stay (28 days) in the general ward (table II).

Table III shows the numbers of patients admitted to the three units during the audit period according to diagnosis. Only nine patients admitted to the intensive care unit had primarily medical conditions, but since a physician participated to some extent in treating all 40 patients they were included when calculating the cost-effectiveness of the admission. Tables IV and V show the running costs of the three wards and the average cost per admission and cost per effective admission. Food consumption is negligible in the intensive care unit, both because patients are few and because they are usually too ill to eat much. Drug and investigation costs are, however, coirespondingly higher, and more senior nurses are employed in this unit. In the adult observation ward patients are also often acutely ill and tend to eat little. Investigations are mainly done in the side room at little cost. Drugs used in the adult observation ward are also simpler and less expensive (drug prescribing is from a limited list similar to the exploratory WHO essential drug list), and laundry costs are lower because often there are no sheets.

Comparison with the admission figures over a full year showed that the intensive care unit was rather busier than usual and the adult observation ward rather less so during the audit. Admissions to the general ward were about average. The ward was similar to the other seven general medical wards but was chosen because one of us was working on it at the time.

\section{Discussion}

There are obvious pitfalls and difficulties in costing medical care in a tropical teaching hospital, but we believe that, though rough, the figures give a fair indication of the relative costs of treating different illnesses in the three types of ward. The 
results are hardly surprising. It is much cheaper to treat an acute curable illness such as malaria than to try to rehabilitate a patient with advanced rheumatic heart disease. The general ward and the intensive care unit may seem expensive, but not in terms of medicine in the Western world. The average cost of treating malaria in a New York hospital ${ }^{2}$ has been calculated at $\$ 1745$, and the bill for one particular patient $(\$ 7702)$ would cover the running costs of the adult observation ward for five weeks.

It is often thought that most tropical illness could be either prevented or treated in dispensaries at little cost. There is much sense in this, but careful inspection of the diseases causing admission suggests that available and economic methods of prevention will have little impact on these admissions. The problem of treating curable diseases at dispensaries is largely one of diagnosis. Certainly many illnesses are accurately diagnosed and treated at dispensaries and health centres, but diagnosis is not always simple. Many of these curable patients arrive at the hospital after two or more visits to dispensaries and hospitals. Clinical diagnosis of even malaria may be wildly inaccurate. ${ }^{3}$ Treatment at any level without a precise diagnosis is likely to be money wasted.

If anything can be done to lower the cost per effective admission it must be in the group 3 and group 4 patients. Unfortunately, it is difficult to see what can be done. Group 4 patients must be admitted, at least initially, to allow a certain diagnosis to be made. Often by the time the incurable nature of the illness has been established patients are too ill to go home. Although help for a group 3 patient is often only temporary, there seems no obvious way (apart from withdrawing medical care) of reducing the expense of managing, for example, diabetic coma or haematemesis from schistosomal portal hypertension.

Finally, the reference hospitals are also teaching hospitals. They teach not only doctors, both undergraduate and postgraduate, but also nurses, physiotherapists, and paramedical staff. Their expense might well be justified by this aspect of their function alone.

We are most grateful to Mr L K Ndungu, senior hospital secretary, for help with the costing; to Mrs J D Ndegwa, medical records officer, and Dr I Sadiqali for their help in collecting data; and to $\mathrm{Dr}$ $\mathrm{H}$ de Glanville, of the African Medical Research Foundation, for much help in preparing the manuscript.

\section{References}

${ }^{1}$ British Medical fournal, 1977, 1, 1117.

2 Kean, B H, and Reilly, P C, American fournal of Medicine, 1976, 61, 159

${ }^{3}$ Rees, P H, et al, East African Medical fournal, 1971, 48, 51.

(Accepted 2 March 1978)

\title{
Bone-marrow relapse in acute lymphoblastic leukaemia in childhood
}

\author{
M A CORNBLEET, JUDITH M CHESSELLS
}

British Medical fournal, 1978, 2, 104-106

\section{Summary and conclusions}

The outcome after bone-marrow relapse was assessed in 53 children with acute lymphoblastic leukaemia (ALL). Twenty-five out of 37 children $(67 \%)$ whose first remission ended in relapse during treatment (group $A$ ) achieved a second remission, as did 15 out of $16(94 \%)$ who relapsed after treatment had been stopped (group B). Nevertheless, the median duration of second remission was only 12 weeks in group $A$ and 35 weeks in group $B$. The median survival from time of relapse was 32 weeks in group $A$ and 75 weeks in group $B$.

It is concluded that marrow relapse is equally serious whether it occurs during treatment or after treatment has been stopped, and that most children with ALL have a single chance of cure at the time of diagnosis.

Department of Haematology, The Hospital for Sick Children, London WC1N 3JH

M A CORNBLEET, BSC, MRCP, leukaemia research fellow

JUDITH M CHESSELLS, MD, MRCP, consultant clinical haematologist

\section{Introduction}

Despite well-publicised advances in managing acute lymphoblastic leukaemia (ALL) in childhood, treatment is ultimately unsuccessful in at least half of all patients. In children with ALL treated with combination chemotherapy and central nervous system (CNS) "prophylaxis" the bone marrow is the most common site of first relapse. We report our experience in managing children with ALL whose first remission ended in haematological relapse, and compare the outcome after relapse during treatment with that following relapse after completing two or three years' chemotherapy.

\section{Patients and methods}

Between 1972 and 1977 bone-marrow relapse ended the first complete remission in 53 children treated at the Hospital for Sick Children (see table). Thirty-seven of these children (group A) had relapsed during treatment and 16 (group B) after treatment had been stopped after two or three years' continuous complete remission. One of the children in group A had a simultaneous marrow and CNS relapse and two children in group $\mathrm{B}$ a simultaneous marrow and testicular relapse.

All children had been treated according to protocols designed by the Medical Research Council Working Party on Leukaemia in Childhood or being piloted for them. All the protocols included prednisolone and vincristine during induction of remission and CNS 